\title{
Recenzió Koltay András $A z$ új média és a szólásszabadság. A nyilvánosság alkotmányos alapjainak újragondolása címú könyvéről
}

\section{SZIKORA TAMÁS ${ }^{1}$}

Koltay András 2019 végén megjelent monográfiája a szólásszabadság elvi alapvetéseinek fényében vizsgálja a társadalmi nyilvánosság számára a digitális tér által hozott kihívások számtalan formáját. A kötet elsö, a szólás- és sajtószabadság alapvetéseit bemutató fejezetét követően a nyilvános kommunikáció formálásában meghatározó szereplővé váló internetes kapuörök szólásszabadsággal kapcsolatos szabályozását érintő elvi jellegü kérdésekre fókuszál. Ezután a szerző három szolgáltatástípus, nevezetesen az internetszolgáltatók, a keresömotorok, majd pedig a social media platformok sajátosságaival összefüggö releváns kérdéseket tárgyalja. A kapuörök szabályozásának jövőjét megelözően pedig az online térben közzétett kommentek sajátosságai tekintetében érvényesülö felelösségi kérdésekbe nyerhet bepillantást az olvasó.

Kulcsszavak: szólásszabadság, közösségi média, keresőmotorok, internetszolgáltatók, társadalmi nyilvánosság

\section{On András Koltay's Book "The new media and the freedom of speech. Rethinking the constitutional foundations of publicity"}

András Koltay's monograph, which was published at the end of 2019, examines countless appearances of the challenges that the digital era brought for the public sphere in the light of the fundamental principles of freedom of speech. After the first chapter introducing the fundamental principles of freedom of speech and freedom of the press, the book focuses on doctrinal issues related to the regulation of freedom of speech issues related to gatekeepers that are becoming key players of shaping public communication. Pursuant to this, the author discusses relevant issues regarding the specificities of three types of services, namely the internet service providers, the search engine providers,

1 PhD-hallgató, NKE Közigazgatás-tudományi Doktori Iskola; kutató, Eötvös József Kutatóközpont Információs Társadalom Kutatóintézet. 
and the social media platforms. Before discussing the future of gatekeeper-regulation, the reader may gain insight to the issues of the specific liability for comments that were published online.

Keywords: freedom of speech social media, search engines, internet service providers, public sphere

Napjaink nyilvánossága merőben más, mint amit korábban tapasztalhattunk - számos alkalommal felmerülhetett már e gondolat a történelem során az éppen adott kor tömegkommunikációs folyamatait vizsgáló, értékelő tudósok, szakemberek részéről. De ahogyan a könyvnyomtatás, a nyomtatott sajtó, majd a rádiós és televíziós műsorszolgáltatások, úgy valószínűsíthetően a mai kommunikációs lehetőségek sem jelentik a technológiai fejlődés végállomását. Mindazonáltal vitathatatlan, hogy számos olyan probléma került napvilágra az internet megjelenése és elterjedése következtében, ami nem nélkülözheti az alapos, részletekbe menő elemzések elvégzését.

E munkák körébe illeszthető Koltay András 2019 végén megjelent monográfiája, amely a szólásszabadság elvi alapvetéseinek fényében vizsgálja a társadalmi nyilvánosság számára a digitális tér által hozott kihívások számtalan formáját. A kötetben vizsgált, a társadalom mindennapi életét - vitathatatlanul - alapjaiban megváltoztató, az online tevékenységeinket minden tekintetben átható szolgáltatások vélhetően jóval nagyobb befolyással vannak életünkre, mint azt korábban gondolhattuk volna. Az internetszolgáltatók, a keresőmotorok, a közösségimédia-platformok, illetve a videómegosztók mind-mind olyan megszokott, elfogadott és nem utolsósorban meghatározó szereplővé léptek elő életünkben, amire korábban valószínűleg igen kevesen gondoltak.

A társadalom mindennapi életét a legapróbb részletekig átszövő és egyben formáló, szinte irányító tényezőjévé váló platformok a kialakulásuk kezdeti fázisában elsődlegesen kommunikációs csatornaként funkcionáló felületekként jelentek meg, azonban idővel jóval túlléptek e kereteiken. Ennek folyományaként pedig a szolgáltatások a szólásszabadság hosszú évszázadokon át kialakuló, formálódó elvi tételeit is komoly kihívások elé állították; Koltay András e kérdéseket, illetve a rájuk adható adekvát válaszokat járja körül tételesen mủvében.

Az eredetileg angol nyelven megjelent kötet ${ }^{2}$ a kifejezetten a magyar nyelvü fordításához elkészült addendum mellett hét fejezetből áll. Egy igen alapos, a szólás- és sajtószabadság alapvetéseit bemutató fejezetet követően a nyilvános kommunikáció formálásában meghatározó szereplővé váló internetes kapuőrök szólásszabadsággal kapcsolatos szabályozását érintő elvi jellegű kérdések átfogó elemzése tárul az olvasó elé. Ezután a szerző három szolgáltatástípus, nevezetesen az internetszolgáltatók, a keresőmotorok, majd pedig a social media platformok sajátosságaival összefüggő

2 András Koltay: New Media and Freedom of Expression. Rethinking the Constitutional Foundations of Public Sphere. Oxford, Hart Publishing, 2019. 
releváns kérdéseket tárgyalja egy-egy fejezet keretében. A kapuőrök szabályozásának jövőjét megelőzően pedig egy unikális véleménynyilvánítási forma, az online térben közzétett kommentek (felhasználói hozzászólások) tekintetében érvényesülő felelősségi kérdések releváns vetületeivel ismerkedhet meg az érdeklődő közönség.

A monográfia teljes hosszát tekintve arányaiban, terjedelmét tekintve leghosszabb, első fejezete a szólás- és sajtószabadság alapvetéseit részletekbe menően ismerteti, a teljesség igényére törekvő elméleti megalapozás azonban nem nélkülözhető, ugyanis a digitális kor kihívásaival, a 21. századi nyilvánossággal kapcsolatban felmerülő kérdésekre csak valamennyi lényeges elméleti szempont átfogó vizsgálata után adható megalapozott válasz. Így, noha a szólás- és sajtószabadság alapvetései között egyes részkérdések első olvasatra feleslegesnek is tủnhetnek, a későbbiekben azonban érthetővé válik, hogy e kérdések vizsgálata, elemzése megkerülhetetlen a nyilvánosság megszokott kereteit feszítő online tér okozta kihívások reménybeli sikeres kezeléséhez vezető úton. Másfelől, amennyiben ezen alaptételek említett részletességủ kifejtését a szerző megspórolta volna, úgy arra sem tudott volna hiteles választ adni, hogy azoknak mely elemei szorulnak esetlegesen újragondolásra, illetve melyek azok, amelyek az online platformok müködésének, szerkezetének sajátosságaitól, véleménybefolyásoló hatásuktól függetlenül érvényesek maradnak.

Az internetes kapuőrök tevékenységét általánosabb formában bemutató második fejezet rávilágít arra, hogy az internetes tartalomszolgáltatások megjelenésével a véleménykifejezés olyan újabb formái jelentek meg, amelyek korábbi szabályozási keretrendszerbe való illeszkedése nem ítélhető meg egyértelműen, és számos új kihívás elé állították (elsődlegesen) a jogalkalmazókat. Így a „beszéd” kategóriájába tartozó megnyilvánulások körének meghatározása sem magától értetődő minden esetben, hiszen például az algoritmusok által összeállított találati listák vagy a közösségi platformokon a felhasználók számára egyedileg összeállított hírfolyamok esete jóval összetett értékelést igényel, mint egy napilapban leírt szöveg. A digitális térben meghatározó jelentőséggel bíró szolgáltatók kapcsán a szerző több olyan releváns jellegzetességükre is rávilágít, amelyek révén alapjaiban képesek formálni a nyilvánosság gondolkodását, cselekvéseit. Mindenképpen ilyennek tekinthető, hogy a jelentősebb internetes kapuőrök (mint amilyen például a Facebook, Google, Twitter, Amazon) szolgáltatói magántulajdonban álló gazdasági társaságok, akik jellemzően az Amerikai Egyesült Államokban telepedtek le, és a felületeiken folyó diskurzusokat aktívan alakító szereplőkké léptek elő.

E fejezet olyan releváns kérdéseket is érint, mint például az említett szolgáltatók jogi megítélése, nevezetesen hogy technológiai cégeknek vagy pedig médiavállalkozásoknak kell-e őket tekinteni. A messze nem csak elméleti jellegủ kérdés tisztázásának szükségességéhez nem férhet kétség, hiszen a kategorizálás súlyos (jogi) következményekkel, vagy éppen ellenkezőleg, azok alóli mentesülési lehetőséggel járhat. Azonban láthatóan nehéz e kérdésekre határozott, megnyugtató válaszokat adni. Ami valóban bizonyosnak látszik, hogy a platformok térnyerését megelőzően alig-alig látott gazdasági erőforrásokkal, illetőleg erőteljes - vagy akár monopolisztikus - piaci befolyással 
bíró vállalkozásokról beszélünk, amelyek tevékenységi köre is jóval túlmutat a véleménybefolyásolás piacán korábban jelentős szerepet betöltő társaságokénál.

A fejezet olvasása során felmerülhet a gondolat az olvasóban, hogy lehetséges-e egyáltalán e piaci óriásokat egyetlen, a korábbi fogalmi rendszereinkben szereplő kategóriák valamelyikébe besorolni, vagy egyes tevékenységeiket kellene inkább önállóan megítélni, és annak megfelelően a vonatkozó alkotmányos alapelveket, jogi szabályokat számon kérni rajtuk. Illetőleg, hogy a kapuőrök eltérő formákban testet öltő véleménybefolyásoló tevékenysége mennyire választható (és ezáltal értkelhető) külön, és nem vezet-e téves eredményre kizárólag annak elemzése, hogy e magatartásuk mennyiben felel meg a szólásszabadság alkotmányos elvárásainak.

A kötet harmadik, terjedelmét tekintve a többitől jóval rövidebb fejezete az internetszolgáltatókat érintő kérdések tisztázására vállalkozik. A kapuőrök e csoportjának az infrastruktúrájukon áthaladó tartalmak szürésében, blokkolásában játszott szerepükre tekintettel a szerző a cenzúra kérdéskörérének értékelésére helyezi a hangsúlyt. Az internetszolgáltatók tevékenysége ugyanis alapvetően abból a szempontból értékelhető a szólásszabadság érvényre juttatása vonatkozásában, hogy milyen intézkedéseket foganatosítanak az egyes (online) tartalmak közönséghez való eljuttatásának korlátozása kapcsán.

Az internetszolgáltatókról szóló rész végén olvasható összegző gondolatokban a szerző igen találóan mutat rá a tapasztalható jelenség ironikus voltára. E szerint kétséges, hogy az internetszolgáltató az általa fenntartott hálózaton „csupán” a tartalmak szabad áramlását biztosító passzív tevékenysége a szólásszabadság gyakorlásának tekinthető. Ezzel szemben ugyanakkor az információáramlás folyamatába beavatkozó (korlátozó) magatartása már egyértelmủ üzenetértékkel bír, amelynek megítéléséhez már nem kerülhetők meg a szólásszabadság elvi tételei sem.

A mủ negyedik és ötödik része a mindennapi életünkre vélhetően legnagyobb hatással lévő és az információszerzés körülményeit, módjait, ezáltal pedig a véleményformálás lehetőségét is a leginkább befolyásoló szolgáltatástípusokkal kapcsolatos problémákat érinti. A más szereplők által előállított online tartalmakat a felhasználó számára egyéni kérésre (kulcsszavak alapján) összegyüjtő és meghatározott szempontok alapján rendszerező (listába állító) keresőmotorok véleménybefolyásoló ereje felől aligha lehet kétség. A szerző nagy részletességgel járja körül a keresőmotorok által adott találati lista beszédjellegét, annak saját tartalomként való minősítésének egyes kérdéseit, illetve e tevékenység szerkesztői magatartással vonható párhuzamait.

A fejezet, azon túlmenően, hogy számos gondolkodásra ösztönző jogeseten keresztül mutatja be az elméleti szinten is vázolt problematikát, amelynek köszönhetően - a mindennapjainkat is e „világban” élőkként - sokkal inkább kézzel foghatóbbá válnak az egyes jelenségek. A szerző nem megy el szó nélkül a keresőmotorok működését leginkább érintő kérdés, nevezetesen az azok elemi feltételének számító algoritmusok megítélése mellett. Nem lehet kétséges, hogy a felhasználók korábbi keresési, illetve általában böngészési tevékenységére alapítottan összeállított találati sorrend létrejöttének hátteréről igen kevés információ kerül nyilvánosságra. A szerző 
részletesen taglalja a felhasználók, keresőmotorok általi esetleges félrevezetésének, manipulációjának problémáját. A felvetés valóban aggodalomra adhat okot, főleg annak tükrében, ha az algoritmusok müködésének átláthatósága a jelenleg nem igazán teljesült elvárások körében említhető, e nélkül pedig tevékenységük jellege sem ítélhető meg teljes bizonyossággal.

A keresőmotorokhoz hasonló léptékủ kérdéseket vetnek fel az ötödik fejezetben tárgyalt közösségimédia-platformok. E körben az olvasó elmélyedhet a véleménykifejezés megváltozott formáinak (például „like” gomb) jogi megítéléséről, a „szűrőbuborék"-elmélettel kapcsolatos összefüggésekről, a sokszínű tájékozódás követelményét, illetve a hírmédiát érintő káros következményekről. A kötet természetesen részletesen foglalkozik e médiafelületek korábbiakban már említett világméretűvé válásával egyre fajsúlyosabb kérdéssé előlépő felelősségi kérdések, illetve a jogérvényesítés lehetséges, jogszerű és egyben hatékony módjainak ismertetésével is.

Látható, hogy a social media felületek számos olyan újszerű problémát hoztak a felszínre, amelyekre korábban talán nem is gondoltunk, mint amilyenek például a több országban bủncselekménynek számító revenge porn, az elhunyt felhasználók adott platformra feltöltött adatainak sorsa, vagy az el nem küldött üzenetek tartalmának elemzése révén az egyén gondolatainak megismerése felé tett lépések ijesztő jelensége. Szintén az újdonság erejével jelenik meg a platformokat érintő szabályozás kérdése: a párhuzamosan egymás mellett érvényesüló állami normák és a platformok által életre hívott közösségi alapelvek furcsa keretet adnak a felhasználók tevékenységének. A szerző rámutat arra, hogy kétfajta normarendszer egyszerre nyújt kiszámíthatatlan és átláthatatlan keretet, illetve azok alkalmazásának következetlenségét is magában hordozza. A platformok így sok esetben az önkény uraként jelennek meg, „ítélkeznek”, akár a jogorvoslathoz, tisztességes és átlátható eljáráshoz való alkotmányos garanciák teljes negligálása mellett; igaz ez akkor is, ha sok esetben valóban az államok kényszere is szerepet játszik e feladatok ellátásának kötelezettségében.

Az online kommentekről szóló hatodik fejezet az európai és a tengerentúli megközelítésen keresztül mutatja be a kommunikáció e formájának jogi megítélése, valamint az effajta tartalmakban megjelentekért viselt felelősség tekintetében gyakorta felbukkanó kérdések okozta anomáliákat. A közös nevező megtalálásához vezető út igen göröngyös voltát jelzik a strasbourgi bíróság ítéletei kapcsán olvasható kritikák. A kommentekben foglaltakért viselt felelősség lehetséges megállapításának több módjára is bemutat példát a szerző: így a polgári jog általános szabályainak, a vonatkozó uniós irányelv ${ }^{3}$ tárhelyszolgáltatók mentességére irányadó normáinak, valamint a kifejezetten e kérdésre vonatkozó speciális elöírások alkalmazását.

A szabályozás jövőjéről szóló fejezet rámutat azon már említett körülményre, miszerint a szólásszabadság korlátozása tekintetében erőteljes hangsúlyeltolódás figyelhető meg az állami szférából a platformok irányába. A kapuőrök által a szólásszabadságot

3 Az Európai Parlament és a Tanács 2000/31/EK irányelve (2000. június 8.) a belső piacon az információs társadalommal összefüggő szolgáltatások, különösen az elektronikus kereskedelem, egyes jogi vonatkozásairól („Elektronikus kereskedelemről szóló irányelv”). 
is érintően hozott döntések korábban nem látott mennyisége, a döntéshozatali mechanizmusok okozta anomáliák valóban tűnhetnek „rémisztőnek” is, bár miután mindennapi életünk szerves részét képező folyamatokról beszélünk, talán már fel sem tünik a felhasználók jelentős részének, és inkább „megszokott” jelenségként érzékelhetők. (Amennyiben nem így volna, vélhetően tömegesen hagynák ott a platformokat; bár az is igaz, hogy erre érdemi alternatíva hiányában nemigen lenne lehetőségük.)

A kötet olvasása kapcsán esetlegesen olyan érzések is támadhatnak az olvasóban, hogy az ismertetett elméleti álláspontok, jogesetek, bírósági ítéletek között tapasztalható ellentétek értékelhetők úgy, hogy nem kivitelezhető a felmerült aggályokat egyetlen jogterület szabályainak alkalmazásával megnyugtatóan rendezni. Helyesnek ítélhető az a meglátás, amely szerint a probléma kezelésére az analógiák alkalmazása nem elvetendő gondolat, de komplex megoldásokat igen csekély eséllyel nyújtanak a jövőbeni szabályozás számára. Már amennyiben egyáltalán a szabályozás tekinthető az egyedüli és lehetséges megoldásnak a kapuőrök müködése kapcsán felmerülő feszültségek megnyugtató rendezésére, vagy pedig e téren is elkerülhetetlen másfajta szemléletmód, és különféle intézkedések együttes alkalmazásában kellene inkább gondolkodni - amelynek természetesen lehet egyik eleme a kötelező érvényü normák számon kérése. 